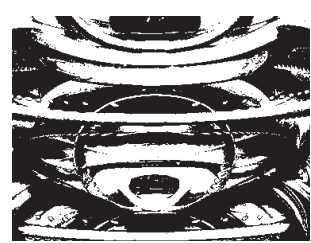

\title{
TO FORGIVE OR NOT TO FORGIVE? BELIEFS ABOUT COSTS AND BENEFITS OF FORGIVENESS, MOTIVATION TO FORGIVE AND WELL-BEING
}

Majda RIJAVEC, Lana JURČEC, Diana OLČAR

Faculty of Teacher Education, Zagreb

UDK: 159.942 .2

Izvorni znanstveni rad

Primljeno: 22. 1. 2013.

The aim of the study was to assess the relationship between beliefs about costs and benefits of forgiveness, motivation to forgive and well-being. Motivation to forgive was measured by TRIM Inventory consisting of three scales - avoidance, revenge and benevolence motivation. Well-being was measured by Life satisfaction scale and PANAS. The scales for measuring beliefs about costs and benefits of forgiveness (CBFS) were specially developed for this study. Two factors of beliefs about benefits of forgiveness (benefits for oneself and benefits for the other/relationship) and two factors of beliefs about costs of forgiveness (failure to protect oneself and failure to educate the offender) were revealed. Results of multiple regression revealed two significant predictors of life satisfaction, belief in benefits of the forgiveness for the other/relationship as positive predictor and failure to protect oneself as cost of forgiveness as negative predictor. Failure to protect oneself and revenge motivation were positive predictors, and belief in benefits of the forgiveness for the other/relationship was negative predictor of negative affect. There were no significant predictors of positive affect. Results suggest that believing in benefits of forgiveness rather than in costs can improve our well-being by increasing life satisfaction and lowering negative affect.

Keywords: forgiveness, motivation to forgive, costs and benefits of forgiveness, well-being

Majda Rijavec, Faculty of Teacher Education, University of Zagreb, Savska cesta 77, 10000 Zagreb, Croatia. E-mail: majda.rijavec@ufzg.hr 
Over the last two decades, a large body of research has explored the concept of forgiveness (for reviews, see Enright \& Fitzgibbons, 2000; McCullough, Pargament, \& Thoresen, 2000; Strelan \& Covic, 2006; Worthington, 2005). In literature forgiveness is usually defined and measured in terms of increased positive and decreased negative affect, cognition, and behaviour in response to personal injury and injustice (Enright, 2001; Rye \& Pargament, 2002). Definitions have included behavioural (Pingleton, 1997), affective (Ferch, 1998), cognitive (Al-Mabuk, Dedrick, \& Vanderah, 1998), and motivational (McCullough et al., 2000) components.

A significant distinction has been drawn between forgiveness as an intra-personal and interpersonal process. Forgiveness as an intra-personal process involves changes within individual cognitions about the offense and forgiveness, while forgiveness as an interpersonal process includes the on-going relationships between the people involved.

Within the interpersonal perspective, there is growing consensus that forgiveness may be defined by prosocial motivational changes towards a transgressor. McCullough (McCullough et al., 1998) defines interpersonal forgiving as the set of motivational changes whereby one becomes (a) decreasingly motivated to retaliate against an offending relationship partner, (b) decreasingly motivated to maintain estrangement from the offender, and (c) increasingly motivated by conciliation and goodwill for the offender, despite the offender's hurtful actions. When an offended person is unable to forgive his/ her perception of the offense produces two motivational states; that is, (a) high motivation to avoid contact with the offending partner (avoidance motivation) and (b) high motivation to seek revenge or see harm come to the offending partner (revenge motivation). The process of forgiving is triggered primarily by increased empathy toward the offender. Similarly, some authors (e.g. Al-Mabuk, Enright, \& Cardis, 1995) see forgiveness as a 'gift' altruistically given to an offender.

In contrast to these other-oriented definitions, some conceptions of forgiveness stress the self-preservation nature of forgiveness. Within these conceptions forgiveness is seen as a means of maintaining important relationships (Ashton, Paunonen, Helmes, \& Jackson, 1998) or a strategy of coping psychologically with the offense (Canale, 1990). Grudge theory (Baumeister, Exline, \& Sommer, 1999) integrates these approaches defining forgiveness as both intrapsychic, taking place in the mind of the forgiver, and interpersonal, or as a social action that happens between people.

Forgiveness can benefit both the relationship and the forgiver. It benefits the relationship as it enables it to survive af- 
DRUŠ. ISTRAŽ. ZAGREB GOD. 22 (2013), BR. 1 STR. 23-40

RIJAVEC, M., JURČEC, L., OLCAR, D.

TO FORGIVE OR NOT.. ter a serious conflict or wrongdoing. It can also benefit the forgiver, both in terms of mental and physical health. Over the past decade, a number of reviews have examined the relationship between forgiveness and well-being (McCullough, 2000; McCullough \& Witvliet, 2002; Thoresen, Luskin, \& Harris, 1998; Witvliet, 2001). These papers suggested that forgiveness, measured in different ways, is positively associated with health. Forgiveness can help us recognize a deeper meaning in the transgression, develop compassion for others, appreciate social support systems, and discover a renewed sense of life purpose (Enright, Freedman, \& Rique, 1998). Empirical studies suggest that forgiveness has potential benefits for physical health (for review see Worthington, Witvliet, Pietrini, \& Miller, 2007), mental health (for a review see Toussaint \& Webb, 2005), and well-being (Karremans, Van Lange, Ouwerkerk, \& Kluwer, 2003; Brown, 2003; Krause \& Ellison, 2003).

Despite the potential benefits of forgiving, scholars have pointed out risks as well (Chagigiorgis \& Paivio, 2007; Malcolm, 2007). For example, offended parties may put themselves or others at risk if their attempts to forgive result in unassertiveness, minimization of serious offenses, suppression of legitimate anger, or misplaced trust in a dangerous person. In addition to that, forgiving may be regarded morally inappropriate (see Lamb \& Murphy, 2002) or costly because it involves letting go of justifiable feelings of anger and resentment (e.g., Exline, Baumeister, Bushman, Campbell, \& Finkel, 2004). The study by Luchies (Luchies, Finkel, McNulty, \& Kumashiro, 2010) indicates that, for some outcomes in some contexts, forgiveness has disadvantages. Forgiving a perpetrator who has not signalled that the victim will be safe and valued has serious negative consequences on one's self-respect and self-concept clarity. Since forgiving, obviously, has its advantages and disadvantages, offended parties often face competing pressures when deciding whether to forgive. The wish to restore the relationship and emotional relief press toward forgiveness, whereas wish for payment encourages resentment.

Several authors have insisted on the fact that the views held on forgiveness strongly impact not only the ability to forgive personal offenses, but also the ability to seek forgiveness. As stated by Casarjian (1992, p. 12), "The beliefs that you hold about forgiveness open or close possibilities for you, determine your willingness to forgive, and, as a result, profoundly influence the emotional tone of your life". With psychological and physical correlates not fully understood, exploring the beliefs about reasons for forgiveness provides an alternative approach to the problem. Cognitions about forgiveness may yield important clues about the nature and consequences of forgiveness (Finkel, Rusbult, Kumashiro, \& Hannon, 2002). 
DRUŠ. ISTRAŽ. ZAGREB GOD. 22 (2013), BR. 1, STR. $23-40$

RIJAVEC, M., JURČEC, L., OLČAR, D. TO FORGIVE OR NOT...
Since forgiving can have both advantages and disadvantages, it is possible that motivation to forgive can be related to personal beliefs about costs and benefits of forgiving. This distinction can be related to two social motives which have been found to influence the relationship processes: motives for advancement (i.e., nourishment, growth, and development), and motives for security (i.e., shelter, safety, and protection; see Bowlby, 1969; Maslow, 1955; Rogers, 1961). These two motives include concerns with advancement (i.e., promotion) and concerns with security (i.e., prevention), which in turn foster different modes of self-regulation (Higgins, 1997; Molden, Lee, \& Higgins, 2008). Self-regulation focused on advancement (or promotion) could motivate forgiveness through the perceived benefits to be attained, while self-regulation focused on security (or prevention) could motivate forgiveness through the perceived costs of further relationship deterioration.

Following this line of thought the first aim of the study was the construction of the scales related to beliefs about benefits and costs of forgiveness. We expected that these beliefs could fall into two categories: those related to costs and benefits for oneself and those related to costs and benefits for the other person/relationship. This is in line with conceptualizations of forgiveness as an intrapsychic process, taking place in the mind of the forgiver, and interpersonal, or a social action that happens between people (Baumeister et al., 1999).

The second aim was to explore the relationship between these beliefs and motivation to forgive. It can be expected that individuals who believe in benefits of forgiveness would be more prone to benevolence motivation toward the transgressor, and less to avoidance and revenge motivation. On the other hand, those who believe more in costs of forgiveness would tend towards avoidance and revenge motivation. There are no clear expectations about whether beliefs in benefits to oneself or the beliefs in benefits for the other/relationship would be more important for motivation to forgive.

The final aim was to assess the relationship between beliefs in costs and benefits of forgiveness, motivation to forgive on one side and well-being on the other. We expected beliefs in benefits of forgiveness and benevolence motivation to be positive predictors of well-being.

\section{METHOD}

\section{Participants}

149 adults (87 females and 62 males) aged from 20 to 62 years participated in this study. All of them were professionals attending additional education for becoming teachers. 


\section{Procedure}

The study was conducted in two phases. In the first phase, items related to beliefs about costs and benefits of forgiveness were collected from participants in order to construct the scales. In the second phase, all instruments were administered to another group of participants. They all voluntarily participated during their regular psychology lectures. For both phases, questionnaires were distributed at the start of a lecture.

\section{Instruments}

Beliefs about costs and benefits of forgiveness - These scales were created by the authors especially for this study. The first stage in developing the scales was to create a list of items that represented a wide range of possible beliefs about costs and benefits of forgiveness. College students and adults, aged from 20 to 60 years $(\mathrm{N}=60)$ were asked to write down their answers to the following questions: "Why is it beneficial to forgive? Why is it costly to forgive?" In the initial stage, over 100 items were collected covering a variety of beliefs about costs and benefits of forgiveness.

Some of these items were identical or had very similar meaning and could be replaced by a single item. The research team shortened the list to 38 items, 21 dealing with benefits and 17 dealing with costs of forgiveness.

The 38 items were presented to participants, using five-point Likert scales, ranging from 1 (completely disagree) to 5 (completely agree).

Transgression-Related Interpersonal Motivations Inventory (TRIM Inventory) - TRIM Inventory was used to assess self-reports of forgiveness (TRIM, McCullough et al., 1998). The scale is comprised of 18 items and three subscales: Avoidance, Revenge, and Benevolence. The seven-item TRIM Avoidance subscale measures the degree to which the offended party intends to reduce contact with the transgressor (e.g., "I live as if he/she doesn't exist, isn't around"). The five-item TRIM-Revenge subscale measures the degree to which the offended party intends to seek revenge on the transgressor (e.g. "I wish that something bad would happen to him/her"). The six-item Benevolence subscale measures the extent to which an individual is motivated to have goodwill or warmth toward another (e.g. "Even though his/her actions hurt me, I have goodwill for him/her"). Response options range from 1 ("Strongly disagree") to 5 ("Strongly agree").

The TRIM is a frequently used self-report measure for the assessment of forgiveness, and evidence of its reliability and validity has been reported (McCullough et al., 1998). In 
DRUŠ. ISTRAŽ. ZAGREB GOD. 22 (2013), BR. 1, STR. $23-40$

RIJAVEC, M., JURČEC, L., OLČAR, D.: TO FORGIVE OR NOT... the present study, the internal reliability estimates were 0.68 , 0.82 and 0.81 for the Revenge, Avoidance and Benevolence subscales respectively.

The Satisfaction with Life Scale (Diener, Emmons, Larsen, \& Griffin, 1985) - The scale measures global life satisfaction as a cognitive-judgemental process. It consists of five statements with a seven-point rating scale ranging from "strongly disagree" to "strongly agree". This scale is a widely used measure of life satisfaction with favourable reliability $($ alpha $=0.93)$ and validity data (Pavot \& Diener, 1993). In this study, a five-point rating scale was used. Cronbach's alpha was 0.83 .

Positive Affect and Negative Affect Schedule (PANAS) (Watson, Clark, \& Tellegen, 1988) - The PANAS-instrument provides a self-assessment of both positive (PA) and negative (PN) general activated affective states. There are 10 adjectives for the NA dimension (such as afraid, ashamed, and nervous) and 10 adjectives for the PA dimension (such as strong, proud, and interested). Respondents were asked to rate the extent to which they have experienced each particular emotion within the past week on a five-grade scale (' 1 ' = "not at all" to ' 5 ' = "very much"). For each participant the responses to the 10 negatively-charged adjectives were summated to provide a total NA-result for NA affect, and similarly, the responses to the positively charged adjectives were summated to provide a total PA-result for PA affect. Reliability and Validity reported by Watson (Watson et al., 1988) were moderately good. For the Positive Affect Scale, Cronbach's alpha coefficient was 0.86 to 0.90; for the Negative Affect Scale, 0.84 to 0.87. The PANAS has a strong reported validity with measures such as general distress and dysfunction, depression, and state anxiety. Cronbach's alpha in this study was 0.87 and 0.90 for the Positive Affect Scale and for the Negative Affect Scale respectively.

\section{Data analysis}

Principal-components analyses with varimax rotation were used to analyse the scales Beliefs about benefits of forgiveness and Beliefs about costs of forgiveness. In order to assess the relationship between beliefs in costs and benefits of forgiveness and motivation to forgive, three linear regression analyses were performed with costs and benefits of forgiveness as predictor variables and avoidance, revenge and benevolence motivation as dependent variables. Three linear regression analyses were performed, with costs and benefits of forgiveness and avoidance, revenge and benevolence motivation as predictor variables and life satisfaction, positive and negative affect as dependent variables. 


\section{RESULTS}

\section{Structure of the scales Beliefs about benefits of forgiveness and Beliefs about costs of forgiveness}

Beliefs about benefits of forgiveness - 21 items were factor analyzed, using principal-components analysis with varimax rotation. The analysis yielded 5 factors with eigenvalues exceeding 1 , accounting for $60.65 \%$ of the total variance. According to scree test, a two-factor solution was forced. Eight items with loadings lower than 0.30 on these factors, or with loading on several factors, were discarded. The final solution included two factors accounting for $54.13 \%$ of the variance.

(1) TABLE 1

Items, factor loadings and Cronbach's alphas for the Beliefs about benefits of forgiveness scale
According to the contents of the items, the first factor was labelled Benefits for oneself and the second factor Benefits for the other/relationship. Items, factor loadings and Cronbach's alphas for these two factors are presented in Table 1.

\begin{tabular}{|c|c|c|c|}
\hline Factors and Items & $\begin{array}{r}\text { Factor } \\
\text { loadings }\end{array}$ & $\begin{array}{c}\% \text { of total } \\
\text { variance }\end{array}$ & $\begin{array}{r}\text { Cronbach's } \\
\text { alpha }\end{array}$ \\
\hline $\begin{array}{l}\text { Factor 1. Benefits for oneself } \\
\text { When we forgive, we can focus energy on positive things } \\
\text { in our life and not on the person who harmed us. } \\
\text { If we manage to forgive, we become a better person. } \\
\text { It is better to forgive than to waste our time and energy } \\
\text { on negative thoughts. } \\
\text { Forgiveness is good for our health. } \\
\text { When we forgive, we feel good. } \\
\text { Forgiveness produces positive emotions. }\end{array}$ & $\begin{array}{l}0.76 \\
0.75 \\
0.69 \\
0.69\end{array}$ & 27.24 & 0.87 \\
\hline $\begin{array}{l}\text { Factor 2. Benefits for the other/relationship } \\
\text { It is good to forgive because it can encourage the other } \\
\text { person to improve. } \\
\text { Forgiveness can turn our enemy into our friend. } \\
\text { Forgiveness makes our friendships stronger. } \\
\text { Forgiveness can make the other person realize } \\
\text { the mistake he/she made. } \\
\text { If the other person is sorry, forgiveness can } \\
\text { restore the relationship. } \\
\text { Forgiveness decreases tension in the relationship. } \\
\text { When we forgive, we show the other person that } \\
\text { we trust them although he/she hurt us. }\end{array}$ & $\begin{array}{l}0.68 \\
0.68 \\
0.68\end{array}$ & 26.89 & 0.80 \\
\hline
\end{tabular}

Benefits for the forgiver include consequences such as focusing energy on positive things in our life and not on the person who harmed us, becoming a better person, not wasting our time and energy on negative thoughts, better health, feeling good and having positive emotions. Benefits for the other/relationship include encouraging the other person to improve, turning our enemy into our friend, making our friend- 
DRUŠ. ISTRAŽ. ZAGREB GOD. 22 (2013), BR. 1, STR. $23-40$

RIJAVEC, M., JURČEC, L., OLCAR, D.

TO FORGIVE OR NOT...

(1) TABLE 2

Items, factor loadings and Cronbach's alphas for the Beliefs about costs of forgiveness scale ships stronger, making the other person realize the mistake, restoring the relationship, decreasing tension and showing the other person our trust. Scale means (Table 3) suggest that participants believe in benefits for oneself to a greater extent than in benefits for the other/relationship $(t=6.821, p=0.001)$.

Beliefs about costs of forgiveness - Seventeen items were factor analyzed, using principal-components analysis with varimax rotation. The analysis yielded 5 factors with eigenvalues exceeding 1, accounting for $57.08 \%$ of the total variance. According to scree test, a two-factor solution was forced. Seven items with loadings lower than 0.30 on these factors, or with loading on several factors, were discarded. The final solution included two factors accounting for $44.21 \%$ of the variance. According to the contents of the items, the first factor was labelled Failure to protect oneself and the second factor Failure to educate the offender. Items, factor loadings and Cronbach's alphas for these two factors are presented in Table 2.

\begin{tabular}{|c|c|c|c|}
\hline Factors and Items & $\begin{array}{r}\text { Factor } \\
\text { loadings }\end{array}$ & $\begin{array}{c}\% \text { of total } \\
\text { variance }\end{array}$ & $\begin{array}{r}\text { Cronbach's } \\
\text { alpha }\end{array}$ \\
\hline $\begin{array}{l}\text { Factor 1. Failure to educate the offender } \\
\text { The offender can do the same thing again. } \\
\text { The offender will not learn. } \\
\text { We should not forgive if there are no positive } \\
\text { consequences either for us or the other person. } \\
\text { Forgiving easily can make the other person } \\
\text { do the same thing again. } \\
\text { We should not forgive if the other person } \\
\text { harmed us intentionally. } \\
\text { Factor 2. Failure to protect oneself } \\
\text { By forgiving we lose our pride. } \\
\text { By forgiving we lose the satisfaction of revenge. } \\
\text { If I forgive, other people can think I am weak and powerless. } \\
\text { If we forgive something important, we go against our beliefs. } \\
\text { We send the other person the message that he/she } \\
\text { can do the same thing to us again. }\end{array}$ & $\begin{array}{l}0.78 \\
0.69 \\
0.53 \\
0.48\end{array}$ & 23.16 & 0.69 \\
\hline
\end{tabular}

Failure to educate the offender included the possibility that the offender could do the same thing again or that forgiving easily could make him/her do it again, that he/she will not learn from the experience, that there would be no positive consequences either for the forgiver or the other person and that we should not forgive if the other person harmed us intentionally. Failure to protect oneself was related to the idea that by forgiving, we lose our pride and satisfaction of revenge, other people can think we are weak and powerless, we go against our beliefs and we send the other person the message that he/she can do the same thing to us again. Scale means (Table 
(1) TABLE 3

Mean Scores and

Standard Deviations of

Beliefs about benefits

of forgiveness scale,

Beliefs about costs of

forgiveness scale, Life

satisfaction scale and

PANAS

(1) TABLE 4

Intercorrelations

among the variables

studied
3) indicate that participants believe that failure to educate the offender is a bigger cost of forgiveness than failure to protect oneself $(t=10.395, p=0.001)$. Generally, it can be concluded from the scale means that participants believe more in benefits than in costs of forgiveness $(t=2.793, p<0.006)$.

Descriptive statistics for Beliefs about benefits of forgiveness scale, Beliefs about costs of forgiveness scale, Life satisfaction scale and PANAS (positive/negative affect) are presented in Table 3. Intercorrelations between the variables studied are shown in Table 4.

\begin{tabular}{|c|c|c|c|c|c|c|c|c|c|c|}
\hline \multicolumn{5}{|l|}{ Subscale } & $\mathrm{N}$ & Min & Max & & M & SD \\
\hline \multicolumn{11}{|l|}{ Benefits of forgiveness } \\
\hline \multirow{2}{*}{\multicolumn{5}{|c|}{$\begin{array}{l}\text { Benefits for oneself } \\
\text { Benefits for the relationship }\end{array}$}} & 149 & 1.67 & 5.00 & 4.1 & 15 & 0.70 \\
\hline & & & & & 149 & 2.14 & 5.00 & 3.8 & 83 & 0.59 \\
\hline \multicolumn{11}{|l|}{ Costs of forgiveness } \\
\hline \multirow{2}{*}{\multicolumn{5}{|c|}{$\begin{array}{l}\text { Failure to protect oneself } \\
\text { Failure to educate the offender }\end{array}$}} & 148 & 1.00 & 4.00 & 2.2 & 27 & 0.72 \\
\hline & & & & & 147 & 1.00 & 4.60 & 2.8 & 83 & 0.67 \\
\hline \multicolumn{11}{|l|}{ Forgiveness } \\
\hline \multirow{3}{*}{\multicolumn{5}{|c|}{$\begin{array}{l}\text { Avoidance motivation } \\
\text { Revenge motivation } \\
\text { Benevolence motivation }\end{array}$}} & 147 & 1.00 & 4.86 & 2.8 & 82 & 0.86 \\
\hline & & & & & 147 & 1.00 & 3.80 & 1.8 & 88 & 0.68 \\
\hline & & & & & 148 & 1.17 & 5.00 & 3.4 & 49 & 0.80 \\
\hline \multicolumn{11}{|l|}{ Well-being } \\
\hline \multirow{3}{*}{\multicolumn{5}{|c|}{$\begin{array}{l}\text { Life satisfaction } \\
\text { Positive affect } \\
\text { Negative affect }\end{array}$}} & 149 & 1.40 & 5.00 & 3.7 & 71 & 0.74 \\
\hline & & & & & 149 & 1.90 & 4.90 & 3.7 & 77 & 0.59 \\
\hline & & & & & 149 & 1.00 & 4.10 & 1.9 & 99 & 0.68 \\
\hline & 1 & 2 & 3 & 4 & 5 & 6 & 7 & 8 & 9 & 10 \\
\hline 1 Benefits for oneself & - & & & & & & & & & \\
\hline 2 Benefits for the relationship & $0.62^{* *}$ & - & & & & & & & & \\
\hline 3 Failure to protect oneself & $-0.43^{* *}$ & $-0.40^{* *}$ & - & & & & & & & \\
\hline 4 Failure to educate the offender & $-0.32^{* *}$ & $-0.39^{* *}$ & $0.56^{* *}$ & - & & & & & & \\
\hline 5 Avoidance motivation & $-0.18^{*}$ & $-0.37^{* *}$ & $0.26^{* *}$ & $0.34^{* *}$ & - & & & & & \\
\hline 6 Revenge motivation & $-0.23^{* *}$ & $-0.24^{* *}$ & $0.42^{* *}$ & $0.40^{* *}$ & $0.32^{* *}$ & - & & & & \\
\hline 7 Benevolence motivation & $0.36^{* *}$ & $0.56^{* *}$ & $-0.28^{* *}$ & $-0.41^{* *}$ & $-0.64^{* *}$ & $-0.43^{* *}$ & - & & & \\
\hline 8 Life satisfaction & $0.26^{* *}$ & $0.33^{* *}$ & $-0.34^{* *}$ & $-0.23^{* *}$ & -0.07 & $-0.24^{* *}$ & 0.14 & - & & \\
\hline 9 Positive affect & 0.15 & $0.18^{* *}$ & $-0.17^{*}$ & -0.10 & -0.09 & -0.16 & 0.13 & $0.44^{* *}$ & * - & \\
\hline 10 Negative affect & -0.11 & $-0.26^{*}$ & $0.33^{* *}$ & 0.17 & 0.09 & $-0.28^{* *}$ & -0.16 & -0.41 & $-0.43^{*}$ & ** - \\
\hline
\end{tabular}

${ }^{*} \mathrm{p}<0.05 ;{ }^{* *} \mathrm{p}<0.001$

\section{Beliefs in costs and benefits of forgiveness and motivation to forgive}

Three linear regression analyses were performed with costs and benefits of forgiveness as predictor variables and avoidance, revenge and benevolence motivation as dependent variables. The results are presented in Table 5 . 


\begin{tabular}{|c|c|c|c|c|c|c|}
\hline & \multicolumn{2}{|c|}{ Avoidance } & \multicolumn{2}{|c|}{ Revenge } & \multicolumn{2}{|c|}{ Benevolence } \\
\hline & $\beta$ & $\mathrm{t}$ & $\beta$ & $\mathrm{t}$ & $\beta$ & $\mathrm{t}$ \\
\hline Benefits for oneself & 0.139 & 1.384 & -0.031 & -0.314 & -0.038 & -0.427 \\
\hline Benefits for the relationship & -0.317 & $-3.131^{*}$ & -0.036 & -0.362 & 0.496 & $5.506^{* *}$ \\
\hline Failure to protect oneself & 0.037 & 0.387 & 0.258 & $2.722^{*}$ & 0.045 & 0.525 \\
\hline \multirow[t]{2}{*}{ Failure to educate the offender } & 0.296 & $3.074^{*}$ & 0.220 & $2.263^{*}$ & -0.259 & $-3.001^{*}$ \\
\hline & \multicolumn{2}{|c|}{$\begin{array}{l}\mathrm{R}=0.459 \\
\mathrm{R}^{2}=0.21\end{array}$} & \multicolumn{2}{|c|}{$\mathrm{R}=0.457$} & $\mathrm{R}=0.596$ & \\
\hline
\end{tabular}

${ }^{*} \mathrm{p}<0.05 ;{ }^{* *} \mathrm{p}<0.001$

(1) TABLE 5 Beliefs about costs and benefits of forgiveness as predictors of avoidance, revenge and benevolence motivation
Beliefs in costs of forgiveness (both failure to educate the offender and failure to protect oneself) are significant positive predictors of revenge motivation. Those participants who believe that it is costly to forgive are more prone to seek revenge towards the offender.

Beliefs that forgiving is beneficial for the other/relationship are a significant negative predictor of avoidance motivation. On the other hand, beliefs that forgiving is costly because it prevents educating the offender are a significant positive predictor of avoidance motivation. Those participants who believe that forgiving can improve the relationship are less prone to avoid the offender, while those who believe that forgiving will result in failure to educate the offender are more prone to avoid him/her.

The opposite relationship was found for the benevolence motivation. Beliefs that forgiving is beneficial for the other/relationship are a significant positive predictor of benevolence motivation. On the other hand, beliefs that forgiving is costly because it prevents educating the offender are a significant negative predictor of benevolence motivation. Those participants who believe that forgiving can improve the relationship are more motivated by conciliation and goodwill for the offender, while those who believe that forgiving will result in failure to educate the offender are less prone to such benevolence motivation.

\section{Beliefs about costs and benefits of forgiveness and motives to forgive as predictors of well-being}

Three linear regression analyses were performed with costs and benefits of forgiveness and avoidance, revenge and benevolence motivation as predictor variables and life satisfaction, positive and negative affect as dependent variables. The results are presented in Table 6.

Linear regression analysis revealed two significant predictors of life satisfaction, belief in benefits of the forgiveness 
(1) TABLE 6

Beliefs about costs and benefits of forgiveness and motives to forgive as predictors of life satisfaction, positive and negative affects protect oneself as cost of forgiveness as a negative predictor. There were no significant predictors of positive affect. Belief in benefits of the forgiveness for the other/relationship was a negative predictor, while failure to protect oneself as cost of forgiveness and revenge motivation were positive predictors of negative affect.

\begin{tabular}{|c|c|c|c|c|c|c|}
\hline & \multicolumn{2}{|c|}{$\underline{\text { Life satisfaction }}$} & \multicolumn{2}{|c|}{ Positive affect } & \multicolumn{2}{|c|}{ Negative affect } \\
\hline & $\beta$ & $\mathrm{t}$ & $\beta$ & $\mathrm{t}$ & $\beta$ & $\mathrm{t}$ \\
\hline Benefits for oneself & 0.049 & 0.461 & 0.078 & 0.700 & 0.107 & 1.037 \\
\hline Benefits for the relationship & 0.262 & $2.291^{*}$ & 0.084 & 0.672 & -0.259 & $-2.239 *$ \\
\hline Failure to protect oneself & -0.238 & $-2.359^{*}$ & -0.141 & -1.280 & 0.252 & $2.479^{*}$ \\
\hline Failure to educate the offender & 0.014 & 0.136 & 0.104 & 0.915 & -0.084 & -0.798 \\
\hline Revenge & -0.172 & -1.835 & -0.099 & -0.974 & 0.268 & $2.844^{*}$ \\
\hline Avoidance & 0.075 & 0.701 & -0.010 & -0.089 & -0.077 & -0.713 \\
\hline \multirow[t]{2}{*}{ Benevolence } & -0.126 & -1.027 & 0.021 & 0.158 & 0.063 & 0.510 \\
\hline & \multicolumn{2}{|c|}{$\mathrm{R}^{2}=0.20^{* *}$} & \multicolumn{2}{|c|}{$\mathrm{R}^{2}=0.06$} & \multicolumn{2}{|c|}{$\mathrm{R}^{2}=0.20^{* *}$} \\
\hline
\end{tabular}

${ }^{*} \mathrm{p}<0.05 ;{ }^{* *} \mathrm{p}<0.001$

Believing in benefits of forgiveness (especially in benefits for the other/relationship) is related to more forgiving and greater well-being (more life satisfaction and less negative affect). On the other hand, believing in costs of forgiveness is related to less forgiving and lower well-being (less life satisfaction and more negative affect).

\section{DISCUSSION}

\section{Beliefs about costs and benefits of forgiveness}

This study was based on the idea that cognitions about forgiveness may yield important clues about its nature and consequences (Finkel et al., 2002). The beliefs that one holds about forgiveness can determine his or her willingness to forgive and, as a result, influence the well-being of the individual. Since forgiveness has both costs and benefits, participants' beliefs about those costs and benefits were investigated as were their relationship to motivation for forgiveness and to well-being.

The beliefs of our participants on the costs and benefits of forgiveness can be divided into two categories. Namely, those related to the costs and benefits for one-self and those related to costs and benefits for the other person or for the relationship. The ideas of our participants corresponded to research data which suggests that forgiveness can benefit both the relationship and the forgiver (Enright et al., 1998; McCullough, 2000). The results suggest that the same may be true for the costs of forgiveness. 


\section{Beliefs about costs and benefits of forgiveness and the motivation to forgive}

These beliefs were relevant for participants' motivation to forgive. Generally, believing in the benefits of forgiveness motivated benevolence rather than avoidance. On the other hand, believing more in the costs of forgiveness predicted more revenge and avoidance, and less benevolence.

It may not be surprising that people act according to their beliefs. However, in this study, beliefs in the benefits or costs of forgiveness were not equally important to predicting motivation for forgiveness. Only those beliefs related to benefits and costs for the other person or the relationship were significant predictors, while those related to benefits and costs for oneself were not predictive.

It can be noted that believing that forgiveness would fail to educate the offender was more important in predicting non-forgiving behaviour than the failure to protect oneself. Evidently, the participants' beliefs about others or the relationship were more important for their motivation to forgive than beliefs related to themselves. Many studies have revealed correlations between empathy and forgiveness (e.g. Exline \& Zell, 2009). Therefore, it is possible that this effect is mediated by empathy or perspective taking.

\section{Beliefs about costs and benefits of forgiveness, motivation to forgive and well-being}

Beliefs about the costs and benefits of forgiveness and the motivation to forgive were related to the well-being of participants but not uniformly across various measures of well-being. Participants with higher life satisfaction were more apt to believe in the benefits of forgiveness to the other person or the relationship, while those with a lower life satisfaction were more concerned by the costs of forgiveness as in failing to protect themselves.

There were no significant predictors of positive affects, while participants with higher negative affects were more prone to revenge motivation, more concerned with the costs of forgiveness in the form of failure to protect themselves and tended less to believe in the benefits of forgiveness for the other person or the relationship. These results can partially be explained by the characteristics of the measure of affective component of well-being used in this study. As was already stated, PANAS (as a measure of affective component of well-being) provides an assessment of only general activated positive and negative affective states. Although researchers have often studied positive and negative affects as unitary states, they can be characterized on a continuous dimension of activation. 
DRUŠ. ISTRAŽ. ZAGREB GOD. 22 (2013), BR. 1 STR. 23-40

RIJAVEC, M., JURČEC, L., OLCAR, D.:

TO FORGIVE OR NOT..
Feldman Barrett and Russell's (1998) conceptualization of affect includes activated and deactivated forms of affects. At the high end of the continuum, positive affects correspond to feeling alert, excited, or elated, while negative affects include feeling nervous, stressed or tense. At the low end of the continuum, positive affects include feeling content, serene or calm, while negative affects include feelings such as sadness, depression or boredom.

This can be offered as an explanation as to why activated positive affects were not predicted by either beliefs of costs or benefits or the motivation to forgive. Unforgiving might be related to negative activated forms of affects, while forgiving might be situated in a more positive and calmer part (Witvliet, 2005). The belief that forgiveness is costly to one-self and revenge motivations are related to feelings such as fear, anger or resentment. It is therefore not surprising that they constitute significant predictors of the negative affects. Whereas, believing that forgiveness is beneficial may be more related to feeling calm, content, or relaxed, which are positive deactivated states not measured by PANAS.

As was already mentioned, it is possible that beliefs in the benefits of forgiveness may be related to the distinction between two social motives: concerns about advancement (i.e., promotion) and concerns about security (i.e., prevention), which in turn foster different modes of self-regulation (Higgins, 1997; Molden et al., 2008). Self-regulation focused on advancement could motivate forgiveness through the perceived benefits to be attained, while self-regulation focused on security could motivate forgiveness through the perceived costs of further relationship deterioration.

Individuals who are promotion-focused (who believe in the benefits of forgiveness) may find opportunities for continued advancement and for attaining further gains in the relationship more relevant than prevention-focused individuals (who believe in the costs of forgiveness). The particular strategies promotion-focused individuals use to pursue their goal primarily involve eagerly seeking gains and advancement, even at the risk of committing errors and accepting losses (Higgins \& Molden, 2003; Molden \& Higgins, 2005; Molden et al., 2008). However, prevention-focused individuals may find greater relevance in their feelings concerning the protection from loss that forgiveness would bring. Their strategies involve vigilantly ensuring security and the absence of losses, even at the risk of forgoing alternative courses of action that could lead to gains (Higgins \& Molden, 2003; Molden \& Higgins, 2005; Molden et al., 2008). This study further develops these ideas by measuring beliefs and costs of forgiveness and relating them to forgiveness motivation and well-being. 
DRUŠ. ISTRAŽ. ZAGREB GOD. 22 (2013), BR. 1, STR. $23-40$

RIJAVEC, M., JURČEC, L., OLČAR, D.

TO FORGIVE OR NOT...
The results of our study suggest that believing in the benefits of forgiveness (especially the benefits to the other/relationship) can be related to more forgiving and greater well-being. It poses the question as to how such beliefs may be increased by means of an intervention. There is evidence that writing about the benefits of an interpersonal transgression facilitates forgiveness (McCullough et al., 2006). In a similar way, writing about the benefits of forgiveness as a therapeutic intervention may be a potentially useful method for helping one to focus more on the benefits than the costs of forgiveness, which in turn may have positive effects on their well-being.

\section{Limitations of the study and future directions}

The nature of our study was correlational and cross-sectional, which prevents conclusions being drawn regarding causality between variables. It is likely that beliefs in the benefits of forgiveness will lead to more motivation to forgive and greater well-being for the reasons discussed in the introduction. On the other hand, it is possible that satisfaction and happiness encourages one to forgive and reinforce their beliefs in the benefits of forgiveness. A longitudinal study would permit closer examination of factors involved in forgiveness and their relations to well-being.

Another liability is related to measurement of positive and negative affect. As was already mentioned, PANAS measures only activated affective states and beliefs about benefits of forgiveness could be more related to inactive positive affects. Future research should include different measures of affective components of well-being.

Moreover, in the process of constructing the scales, participants were asked to state their beliefs about why it is good to forgive and why it is not good to forgive. The context or the relationship with the offender were not stated. It is possible that participants, while stating their beliefs, evoked more situations that included close relationships. Close relationships might arouse beliefs in the benefits of forgiveness because the offended person can leave the relationship only through significant personal sacrifice (Mitchell, Holtom, Lee, Sablynski, \& Erez, 2001). Some studies (e.g. Karremans et al., 2003) suggest that forgiveness and psychological adjustment are related much more strongly in relationships in which the individual is strongly committed. Future research should include these variables in the study of the relationship between beliefs about costs and benefits of forgiveness, motivation to forgive and well-being. 
Al-Mabuk, R. H., Dedrick, C. V. L., \& Vanderah, K. M. (1998). Attribution retraining in forgiveness therapy. Journal of Family Psychotherapy, 9(1), 11-30. doi:10.1300/J085V09N01_02

Al-Mabuk, R. H., Enright, R. D., \& Cardis, P. A. (1995). Forgiveness education with parentally love-deprived late adolescents. Journal of Moral Education, 24(4), 427-444. doi:10.1080/0305724950240405

Ashton, M. C., Paunonen, S. V., Helmes, E., \& Jackson, D. N. (1998). Kin altruism, reciprocal altruism, and the Big Five personality factors. Evolution and Human Behavior, 19(4), 243-255. doi:10.1016/S10905138(98)00009-9

Baumeister, R. F., Exline, J. J., \& Sommer, K. L. (1999). The victim role, grudge theory, and two dimensions of forgiveness. In E. L. Worthington, Jr. (Ed.), Dimensions of forgiveness: Psychological research and theological perspectives (pp. 79-104). Philadelphia: Templeton Foundation Press.

Bowlby, J. (1969). Attachment and loss (Vol. 1), Attachment. New York: Basic Books.

Brown, R. P. (2003). Measuring individual differences in the tendency to forgive: Construct validity and links with depression. Personality and Social Psychology Bulletin, 29(6), 759-771. doi:10.1177/ 0146167203029006008

Canale, J. (1990). Altruism and forgiveness as therapeutic agents in psychotherapy. Journal of Religion and Health, 29(4), 297-301. doi:10. 1007/BF00992984

Casarjian, R. (1992). Forgiveness: A bold choice for a peaceful heart. New York: Bantam Books.

Chagigiorgis, H., \& Paivio, S. (2007). Forgiveness as an outcome in emotion-focused trauma therapy. In W. Malcolm, N. DeCourville, \& K. Belicki (Eds.), Women's reflections on the complexities of forgiveness (pp. 121-141). New York, US: Routledge/Taylor \& Francis Group.

Diener, E., Emmons, R., Larsen, J., \& Griffin, S. (1985). The Satisfaction With Life Scale. Journal of Personality Assessment, 49(1), 71-75. doi:10.1207/s15327752jpa4901_13

Enright, R. D. (2001). Forgiveness is a choice: A step-by-step process for resolving anger and restoring hope. Washington DC: American Psychological Association.

Enright, R. D., \& Fitzgibbons, R. P. (2000). Helping clients forgive: An empirical guide for resolving anger and restoring hope. Washington, DC: American Psychological Association. doi:10.1037/10381-000

Enright, R. D., Freedman, S., \& Rique, J. (1998). The psychology of interpersonal forgiveness. In R. D. Enright, \& J. North (Eds.), Exploring forgiveness (pp. 46-62). Madison, WI: University of Wisconsin Press.

Exline, J. J., \& Zell, A. L. (2009). Empathy, self-affirmation, and forgiveness: The moderating roles of gender and entitlement. Journal of Social and Clinical Psychology, 28(9), 1071-1099. doi:10.1521/jscp.2009. 28.9.1071 
DRUŠ. ISTRAŽ. ZAGREB GOD. 22 (2013), BR. 1, STR. $23-40$

RIJAVEC, M., JURČEC, L., OLCAR, D.

TO FORGIVE OR NOT...
Exline, J. J., Baumeister, R. F., Bushman, B. J., Campbell, W. K., \& Finkel, E. J. (2004). Too proud to let go: Narcissistic entitlement as a barrier to forgiveness. Journal of Personality and Social Psychology, 87(6), 894-912. doi:10.1037/0022-3514.87.6.894

Feldman Barrett, L., \& Russell, J. A. (1998). Independence and bipolarity in the structure of current affect. Journal of Personality and Social Psychology, 74(4), 967-984. doi:10.1037/0022-3514.74.4.967

Ferch, S. R. (1998). Intentional forgiving as a counseling intervention. Journal of Counseling and Development, 76(3), 261-270. doi:10.1002/ j.1556-6676.1998.tb02541.x

Finkel, E. J., Rusbult, C. E., Kumashiro, M., \& Hannon, P. A. (2002). Dealing with betrayal in close relationships: Does commitment promote forgiveness? Journal of Personality and Social Psychology, 82(6), 956-974. doi:10.1037/0022-3514.82.6.956

Higgins, E. T. (1997). Beyond pleasure and pain. American Psychologist, 52(12), 1280-1300. doi:10.1037//0003-066X.52.12.1280

Higgins, E. T., \& Molden, D. C. (2003). How strategies for making judgments and decisions affect cognition: Motivated cognition revisited. In G. V. Bodenhausen, \& A. J. Lambert (Eds.), Foundations of social cognition: A festschrift in honor of Robert S. Wyer, Jr (pp. 211-236). Mahwah, NJ: Lawrence Erlbaum Associates.

Karremans, J. C., Van Lange, P. A. M., Ouwerkerk, J. W., \& Kluwer, E. S. (2003). When forgiveness enhances psychological well-being: The influence of interpersonal commitment. Journal of Personality and Social Psychology, 84(5), 1011-1026. doi:10.1037/0022-3514.84.5.1011

Krause, N., \& Ellison, C. G. (2003). Forgiveness by God, forgiveness of others, and psychological well-being in late life. Journal for the Scientific Study of Religion, 42(1), 77-93. doi:10.1111/1468-5906.00162

Lamb, S., \& Murphy, J. G. (Eds.) (2002). Before forgiving: Cautionary views of forgiveness in psychotherapy. New York: Oxford University Press. doi:10.1093/acprof:oso/9780195145205.001.0001

Luchies, L. B., Finkel, E. J., McNulty, J. K., \& Kumashiro, M. (2010). The doormat effect: When forgiving erodes self-respect and self-concept clarity. Journal of Personality and Social Psychology, 98(5), 734-749. doi:10.1037/a0017838

Malcolm, W. (2007). The timeliness of forgiveness interventions. In W. Malcolm, N. DeCourville, \& K. Belicki (Eds.), Women's reflections on the complexities of forgiveness (pp. 275-292). New York, NY, US: Routledge/Taylor \& Francis Group.

Maslow, A. (1955). Deficiency motivation and growth motivation. In M. Jones (Ed.), Nebraska symposium on motivation (pp. 1-30). Lincoln, Nebraska: Univ. of Nebraska Press.

McCullough, M. E., Root, L. M., \& Cohen, A. D. (2006). Writing about the benefits of an interpersonal transgression facilitates forgiveness. Journal of Consulting and Clinical Psychology, 74(5), 887-897. doi:10. 1037/0022-006X.74.5.887

McCullough, M. E., Pargament, K. I., \& Thoresen, C. E. (Eds.) (2000). Forgiveness: Theory, research, and practice. New York: Guilford. 
DRUŠ. ISTRAŽ. ZAGREB GOD. 22 (2013), BR. 1 STR. $23-40$

RIJAVEC, M., JURČEC, L., OLČAR, D.:

TO FORGIVE OR NOT..
McCullough, M. E. (2000). Forgiveness as human strength: Theory, measurement, and links to well-being. Journal of Social Clinical Psychology, 19(1), 43-55. doi:10.1521/jscp.2000.19.1.43

McCullough, M. E., Rachal, K. C., Sandage, S. J., Worthington, E. L., Jr., Wade-Brown, S., \& Hight, T. (1998). Interpersonal forgiving in close relationships: II. Theoretical elaboration and measurement. Journal of Personality and Social Psychology, 75(6), 1586-1603. doi:10.1037/ 0022-3514.75.6.1586

McCullough, M. E., \& Witvliet, C. V. (2002). The psychology of forgiveness. In C. R. Snyder, \& S. J. Lopez (Eds.), Handbook of positive psychology (pp. 446-458). Oxford: Oxford University Press.

Mitchell, T., Holtom, B., Lee, T., Sablynski, C., \& Erez, M. (2001). Why people stay: Using job embeddedness to predict voluntary turnover. Academy of Management Journal, 44(6), 1102-1121. doi:10.2307/3069391

Molden, D. C., \& Higgins, E. T. (2005). Motivated thinking. In K. Holyoak, \& B. Morrison (Eds.), Handbook of thinking and reasoning (pp. 295-320). New York: Cambridge University Press.

Molden, D. C., Lee, A. Y., \& Higgins, E. T. (2008). Motivations for promotion and prevention. In J. Shah, \& W. Gardner (Eds.), Handbook of motivation science (pp. 169-187). New York: Guilford.

Pavot, W., \& Diener, E. (2009). Review of the satisfaction with life scale. Social Indicators Research Series, 39, 101-117. doi:10.1007/978-90481-2354-4_5

Pingleton, J. P. (1997). Why we don't forgive: A biblical and object relations theoretical model for understanding failures in the forgiveness process. Journal of Psychology and Theology, 25(4), 403-413.

Rogers, C. R. (1961). On becoming a person. Boston: Houghton.

Rye, M. S., \& Pargament, K. I. (2002). Forgiveness and romantic relationships in college: Can it heal the wounded heart? Journal of Clinical Psychology, 58(4), 419-441. doi:10.1002/jclp.1153

Strelan, P., \& Covic, T. (2006). A review of forgiveness process models and a coping framework to guide future research. Journal of Social and Clinical Psychology, 25(10), 1059-1085. doi:10.1521/jscp.2006.25.10.1059

Thoresen, C. E., Luskin, F., \& Harris, A. H. S. (1998). Science and forgiveness interventions: Reflections and recommendations. In E. L. Worthington (Ed.), Dimensions of forgiveness (pp. 163-192). Philadelphia: Templeton Foundation.

Toussaint, L., \& Webb, J. R. (2005). Theoretical and empirical connections between forgiveness, mental health, and well-being. In E. L. Worthington, Jr. (Ed.), Handbook of forgiveness (pp. 349-362). New York: Routledge.

Watson, D., Clark, L. A., \& Tellegen, A. (1988). Development and validation of brief measures of positive and negative affect. The PANAS scales. Journal of Personality and Social Psychology, 54(6), 1063-1070. doi:10. 1037//0022-3514.54.6.1063

Witvliet, C. V. O. (2001). Forgiveness and health: Review and reflections on a matter of faith, feelings, and physiology. Journal of Psychology and Theology, 29, 212-224. 
DRUŠ. ISTRAŽ. ZAGREB GOD. 22 (2013), BR. 1, STR. $23-40$

RIJAVEC, M., JURČEC, L., OLČAR, D.:

TO FORGIVE OR NOT.
Witvliet, C. V. O. (2005). Unforgiveness, forgiveness, and justice: Peripheral physiology findings. In E. L. Worthington, Jr. (Ed.), Handbook of forgiveness (pp. 305-320). New York: Brunner-Routledge.

Worthington, E. L., Jr. (Ed.) (2005). Handbook of forgiveness. New York: Routledge.

Worthington, E. L., Witvliet, C., Pietrini, P., \& Miller, A. J. (2007). Forgiveness, health, and well-being: A review of evidence for emotional versus decisional forgiveness, dispositional forgivingness, and reduced unforgiveness. Journal of Behavioral Medicine, 30(4), 291-302. doi:10.1007/s10865-007-9105-8

\section{Oprostiti ili ne? Vierovanja o koristi i šteti od opraštanja, motivacija za opraštanje i dobrobit}

Majda RIJAVEC, Lana JURČEC, Diana OLČAR

Učiteljski fakultet, Zagreb

Cilj istraživanja bio je ispitati odnos između vierovanja o koristi i šteti od opraštanja, motivacije za opraštanje i dobrobiti. Motivacija za opraštanje mjerena je TRIM inventarom, koji se sastoji od tri skale - izbjegavanje, osveta i dobronamjernost. Dobrobit je mjerena Skalom životnoga zadovolistva i PANAS upitnikom pozitivnih i negativnih afekata. Skale za mjerenje vierovanja o šteti i koristi od opraštanja konstruirane su za potrebe ovog istraživanja. Faktorska analiza rezultirala je dvama faktorima vierovanja o koristi od opraštanja (korist za sebe i korist za drugu osobu/odnos) i dvama faktorima vierovanja o šteti od opraštanja (neuspjeh da se zaštitimo i neuspjeh da educiramo osobu koja nas je povrijedila). Provedene su višestruke regresijske analize sa životnim zadovoljstvom, pozitivnim i negativnim afektima kao kriterijskim varijablama te vjerovanjima o šteti i koristi od opraštanja i motivacijom za opraštanje kao prediktorskim varijablama. Značajnim prediktorima životnoga zadovoljstva pokazali su se vjerovanje u korist za drugu osobu/odnos kao pozitivan prediktor i neuspjeh da se zaštitimo kao negativan prediktor. Neuspjeh da se zaštitimo i motivacija za osvetom bili su pozitivni prediktori, dok je korist za odnos bila negativan prediktor negativnih afekata. Nije bilo značajnih prediktora pozitivnih afekata. Rezultati pokazuju da vjerovanja u koristi opraštanja više nego u štetu mogu unaprijediti našu dobrobit povećavajući životno zadovoljstvo i smanjujući negativne afekte.

Ključne riječi: opraštanje, motivacija za opraštanje, koristi i štete od opraštanja, dobrobit 